\title{
Arctic narratives: brewing a brand with neolocalism
}

\author{
Janne P. Ikäheimo ${ }^{1}$ (1) \\ Revised: 7 January 2021 / Accepted: 21 January 2021 / Published online: 16 February 2021 \\ (c) The Author(s) 2021
}

\begin{abstract}
Neolocalism has been identified as an important component in the current boom in microbreweries. When constructed actively and consciously, it can also be deployed in marketing as a method of brand-related storytelling. This argument is strengthened here through a case study focusing on Tornio Brewery, a microbrewery located near the southern edge of the Arctic in northern Finland. The qualitative research method used here involves the identification of stories related to neolocalism from the brand narrative composed of media releases, advertisements and other promotional material, in addition to beer names and labels. The themes emerging from this material-history and heritage, Lapland and the Arctic as geographic locations, the use of local ingredients and community involvement, as well as the culture and heritage of northern Finlandare then explored. Neolocalism is shown to provide a rich vein of storytelling that can be used effectively for marketing purposes as a holistic concept. While craft brewers have already explored neolocalism in their marketing efforts, the use of professional assistance in creating all-encompassing and meditated storylines is strongly recommended.
\end{abstract}

Keywords Arctic $\cdot$ Brewery $\cdot$ Brand $\cdot$ Storytelling $\cdot$ Neolocalism $\cdot$ Place

\section{Introduction}

The present study contributes to brand management literature by exploring the multi-faceted relationship of storytelling-based brand narrative and neolocalism. Neolocalism, "a conscious effort by businesses to foster a sense of place based on attributes of their community" (Holtkamp et al. 2016, p. 66), has received substantial and prolonged attention in the context of microbreweries and craft beer (e.g., Flack 1997; Schnell and Reese 2003; Garavaglia 2020) since the introduction of the concept by Shortridge (1996). While the early studies focused on identifying the most obvious expressions of neolocalism in beer names and labels, their significance to the marketing of craft beer and brand management has lately attracted growing attention (e.g., Sjölander-Lindqvist et al. 2019; Melewar and Skinner 2020). These studies have confirmed the notion that local ties are cultivated intentionally rather than by necessity (Zelinsky 2011), and not only constructed, as they also need to be

Janne P. Ikäheimo

janne.ikaheimo@oulu.fi

1 Archaeology, University of Oulu, P.O. Box 1000, 90014 Oulu, Finland maintained actively (Schnell and Reese 2003, 2014; Schnell 2013).

Due to these qualities, neolocal themes and motives can be and have been deployed systematically in marketing as brand narratives to create positive associations with the product (Herskovitz and Crystal 2010). But as fact-based narratives tend to grow into complex and precarious constructions that are seldom, if ever, suitable for generating a brand narrative (Pulizzi 2012), storytelling has become increasingly common in brand marketing. When taken to the extreme, the storytelling-based brand image rather than the actual product may constitute the main asset of the company, and, on conceptual level, the customers get a free product along with their purchase of the brand (see Firat and Venkatesh, 1993; Boutlis, 2000).

Yet, the question of how successful stories are woven around the product(s) in a specific spatial context (Lundqvist et al 2013) and how they are actively maintained to establish corporate identity is a somewhat neglected theme in research. Therefore, the expressions of neolocalism will be explored here through a case study involving an in-depth analysis of place-related brand marketing strategies of a single microbrewery. With active storytelling forming the core marketing strategy, localness and the sense of place can be produced, reproduced, appropriated and maintained 
in a multitude of ways to add distinctiveness to the products of a corporate operating in a highly competitive marketing environment.

It will be also demonstrated that while a credible and fascinating brand story is not necessarily objective or authentic, it is intimately linked with the production and may involve various communicative and performative acts (Rose et al. 2016) while being saturated with various modes of establishing the sense of place that ultimately aid at the creation of a local, regional or even a national brand. A good story that may be a fabrication to a varying degree with thematically resonating imagery is shown to be essential for gaining the support of the local population and, in turn, for guaranteeing the longevity of the business venture.

Thus, as the main intention is to discuss the concept of neolocalism and its implications in the context of brand management, the remainder of this paper is structured as follows. First, a two-part literature review will be presented. The first part focuses on the concept of neolocalism and its application in the field of craft beer and microbrewery studies. The second part outlines how the past and recently also the place have become central topics of interest in storytelling-based brand marketing. They are followed by arguments justifying the case selection and the methodology applied to it. The research material, presented in four subsequent chapters, is followed by a two-part discussion. The first part is reserved for case-specific observations, while the second part lays out the wider managerial implications of the study in brand marketing. Finally, the main findings of the research will be reviewed in conclusions.

\section{Literature review}

\section{Neolocalism and microbreweries}

Interestingly, much of the research concerning the concept of neolocalism has focused on the craft beer revolution propelled by a rapidly increasing number of microbreweries around the globe. As microbreweries appear to be rooted in place, they "are marketing 'place' as much as they are marketing beer, and they actively seek out distinctly local imagery, local landscapes, and local stories to position themselves as intrinsically rooted in place" (Schnell 2013, p. 57). Local ingredients can also be sourced in craft brewing to establish the image of a business strongly integrated with the local community (see Schnell and Reese 2014; Fletchall 2016; Sjölander-Lindqvist et al. 2019), although this is not overly common due to their uneven availability (Schnell 2013; Schnell and Reese 2014).

Nevertheless, the use of local ingredients has been identified as a viable way for craft brewers to increase their material authenticity (Thurnell-Read 2019) as ecological production is currently a popular business trend, and it is very important for the marketing of craft beer (e.g., Jones 2017; Withers 2017). One valid path to verify this has been the study of the preferences of microbrewery clients and their relation to neolocal values (Fletchall 2016; Graefe et al. 2017). The results indicate that increased localness has a positive effect on the business, although the clients do not always consciously seek to experience it by consuming the products or by visiting brewery-related establishments.

Since Flack's (1997) seminal paper on American microbreweries and neolocalism, scholars have mainly used beer names and labels, brand narratives based on local stories, and other types of textual and visual marketing lore as their principal research material. The geographic focus of research data has varied from regional (e.g., Fletchall 2016) through national (e.g., Eberts 2014; Garavaglia 2020) and continental (e.g., Schnell and Reese 2014) to the global (Hede and Watne 2013) level. All these studies have reached the same basic conclusion: microbreweries make conscious efforts to deploy neolocalism to enhance the sense of place. The earlier scholarship has also successfully surveyed the substance and methods of establishing the sense of place through various types of references, such as history, heritage, geography and nature (e.g., Eberts 2014).

A recent study (Holtkamp et al. 2016) has also introduced a method to quantify the amount of neolocalism shown by microbreweries with an assessment tool based on three main categories of indicators identified through literature survey: (1) local names and images used in labeling and marketing; (2) environmental sustainability; and (3) social and community engagement. While the assemblage of microbreweries piloted with this method obtained relatively low scores on neolocalism, based on the information given at their web sites, the authors made a strong argument about the applicability of their assessment tool (Holtkamp et al. 2016). This assessment tool has been further refined and modified by Taylor Jr and DiPietro (2020), whose results suggest that enhanced neolocalism contributes positively to customer satisfaction.

However, the notion about the association of neolocalism with local microbreweries has recently been challenged by Debies-Carl (2019) with quantitative data indicating that the breweries operating on a regional rather than on local or global scale are the ones resorting most often to neolocal values. But, because "local" as a definition is context dependent, it is often rendered visible only by its binary opposition that is "global" (Schnell 2013). Thus, as neolocalism has not only resulted from but has also been enabled by globalism, this contrast has been explored in the branding and marketing of craft beer.

A common undertone for many of these contributions is that while they present the use of neolocalism in craft beer branding and marketing as a planned and common trait 
(e.g., Schnell and Reese 2014), it is inherently assumed to be candid and not overtly sales-oriented (e.g., Maguire et al. 2017). A quote from an article examining the craft beer market in Argentina- "craft beer movement around the world has been making genuine connections with people and local idiosyncrasies" (Belmartino and Liseras 2020)_exemplifies this attitude. As a result, neolocal is seen something that is "authentic, familiar and connected to place" (Eberts 2014, p. 198) instead of being fabricated, intrusive, and universal like its binary opposite, globalization (Schnell 2013).

Yet, a considerable degree of intentionality can be weaved into the expressions of neolocal through storytelling (e.g., Schnell and Reese 2014). In this process of "enrichment," the story that is told has not to be necessarily true, if it is good and properly narrated (Thurnell-Read 2019). For this reason, many microbreweries have exploited folklore, local myths as well as tales about local heroes in their narrative, which also represents a viable way to humanize their brand (Hede and Watne 2013). While the importance of such neolocal narratives has been acknowledged, and some reallife examples have been inserted as vignettes to enliven otherwise generalizing and synthesizing treatises (e.g., O'Brien 2020), also the lack of research focusing on associated business practices has been identified (Holtkamp et al. 2016). This article attempts to fill this gap by presenting a case described and analyzed in the pages following the review on the use of concepts of past and place in brand marketing.

\section{Past and place in brand storytelling}

Due to enhanced neolocalism communicated through brandrelated storytelling, craft breweries have recently been identified as place-based brands (Taylor Jr and DiPietro 2020). Organizational and brand-related storytelling have been studied in the context of brand management quite intensively after the publication of Boje's (1995) seminal paper on Disney focusing "upon the storytelling work that people perform." As storytelling was identified as a universal system that resides outside the people doing the storytelling work, it was early on recognized as a viable way of communication in a business environment (e.g., Kaufman 2003; Fog et al. 2005; Barker and Gower 2010). The connection that narratives establish between consumers and brands was later on elaborated by Escalas (2004), who postulated that narratives act as components in a meaning-making process that consumers utilize to connect with and even to incorporate the brand into their sense of self. This connection is emotional and based on authenticity, implying that to accept the brand story the consumer must associate it with reality (Chiu et al. 2012).

While stories are narratives about past events, the act of telling them at present has an aim in the future (Kaufman 2003). In the brand marketing context, this topic has been extensively researched by J.M.T. Balmer and M. Burghausen, who have also elaborated the categorization of various past-related corporate-level concepts like corporate heritage brand and heritage brand (e.g., Burghausen and Balmer 2014a, 2014b; Balmer and Burghausen 2019). Their main conclusion is that when managed the right way, the past can be turned into a precious and important asset with great relevance for the future (e.g., Burghausen and Balmer 2014b; Wilson 2018; Balmer and Burghausen 2019). The past can therefore form an exploitable resource for corporate branding, marketing, and communication (Burghausen and Balmer 2014a, 2014b). This can be done by narrating, visualizing, performing, and embodying the past with links to the historical materials that are relevant within the wider societal context (Burghausen and Balmer 2014a; Wilson 2018).

But while the past per se represents an important and potentially beneficial resource for companies, which can be referred to using several modes, corporate heritage may also be completely or partially fictitious (Balmer and Burghausen 2019; Brunninge and Hartmann 2019). When constructed for marketing purposes in the present as invented corporate heritage, the consumers may perceive such glorified or "adopted" (Burghausen and Balmer 2014b) past as authentic. Not only does the past contain deployable symbolic resources to enhance the feeling of "genuineness," but the impression of continuity makes even far-fetched stories palatable to the consumers (Brunninge and Hartmann 2019).

Thus, a good brand story improves brand attitudes and enhances purchase intentions, if it contains enough factual or spatio-temporal cues to appear authentic (Chiu et al. 2012). However, it is proposed that people do not necessarily believe in these authenticity myths but have a cultural craving for them despite being simultaneously aware of their status as fiction (O'Neill et al. 2014). When the impact of storytelling on the consumer brand experience has been studied, the results suggest that storytelling may exceed packaging in importance (Lundqvist et al 2013). Corporate heritage branding through storytelling represents a distinct form of place branding, in which place is used to add distinctiveness to corporate identity and marketing strategies (Wilson 2018; Spielmann et al. 2019). In such a case, a fictitious story "relies on links with history, heritage or past events in a place, resulting in the construction or invention of a heritage narrative" (Spielmann et al. 2019, p. 9).

On the other hand, the concept of "terroir" has recently gained intensified attention in marketing and management literature due to renewed interest in place branding. While previously perceived through economic and relational logic as a synonym of the physical region determined by environmental conditions like soil, climate and topography, social, historical and cultural factors are today stressed as equally important constituents for assigning uniqueness to local 
produce (Riviezzo et al. 2017; Sjölander-Lindqvist et al. 2019; Smith Maguire and Charters 2020). As these placespecific values and meanings are difficult, if not impossible, to replicate, they might constitute a way to achieve distinctive positioning in the marketing context (Riviezzo et al. 2017, see also Spielmann et al. 2019). Even emotions and feelings associated with a place, which are of primary importance in place attachment, can be exploited in placebased branding (Taylor Jr and DiPietro 2020). The concept of terroir is therefore dynamic, complex and multi-faceted by the very nature (Riviezzo et al. 2017; see also Wilson 2018).

Location, place and social ties play also an important role in craft brewing. This is reflected in company and beer names, beer labels and other imagery in addition to narratives linking the products with a place in social media (Sjölander-Lindqvist et al. 2019). The effect of specific geographic origin with related brand management decisions has recently been explored in two studies: one focusing on a Corfiot microbrewery in Greece (Melewar and Skinner 2020) and another studying several microbreweries currently active in the province of Jämtland, northern Sweden (Sjölander-Lindqvist et al. 2019: 150). The latter study corroborates the observation that the production and marketing of craft beer can be connected to place and locality through local mythology, nature, and social networks to the point that "social terroir becomes a critical ingredient in the production of craft beer" (Sjölander-Lindqvist et al. 2019, p. 158).

Yet, there is a pronounced lack of research focusing not only on the combination of place branding and corporate heritage (Wilson 2018), but also on the combination of beer, terroir and sense of place (Melewar and Skinner 2020). Therefore, this contribution attempts to assess these issues from a qualitative point of view by presenting a single case that explores "implications for current theory and conceptualizations of the issues" (Buchanan 1999, p. S77). The materials and methods used to accomplish this will be described next.

\section{The case: Tornio Brewery}

The subject of this case study, Tornion Panimo (en. Tornio Brewery), is a microbrewery located in Finland. In this Nordic country, the brewing industry has developed along the lines of more intensively researched beer-producing countries like the USA, Great Britain and Canada, although at a slightly slower pace and a much smaller scale. In short, by the end of the 1980s, domestic beer was produced in Finland only by three macrobreweries. These breweries started to carry out heavy rationalization programs by closing down satellite breweries acquired through corporate merging before they were themselves merged into global brewing giants (Turunen 2002). The first wave of microbreweries began in the late 1990s, mainly in the form of beer restaurants and brewpubs, which numbered about 40 in 2000 . However, only 16 of them were in operation in 2004, when their number was lowest. By 2016, the number of microbreweries had increased quite steadily to 60 , and currently, there are ca. 110 microbreweries operating in Finland.

The geographic distribution of Finnish microbreweries is heavily weighted toward the southern part of the country. Only two microbreweries hail from Lapland, the northernmost region of Finland, which is sparsely inhabited $(<2$ inhabitants per $\mathrm{km}^{2}$ ) but constitutes nearly a third of the country's land area. Tornio Brewery is the other of these two breweries, as it was established in early 2016 in the eponymous town of Tornio, located by the Swedish border in southwestern Lapland (Fig. 1). The brewery operates there within the old brewing facilities of Finnish macro brewery Lapin Kulta Oy (Lapland's Gold Inc.) that was closed down by Heineken N.V. in 2010-just two years after its acquisition from the Finnish beverage conglomerate Hartwall. While Lapin Kulta Oy put out ca. 2 million hectoliters of beer (ca. 1.7 million US beer barrels) per annum in its heyday, Tornio Brewery's production in 2018 measured ca. 0.003 million barrels (Pint General 2019). The Finnish law defines a microbrewery as a brewery with a maximum annual output of 0.15 million hectoliters $(\approx 0.125$ million barrels).

Tornio Brewery has been chosen as a case not only for its peculiar historical background and particular geographic context. Namely, the brewery has published an exceptional array of press releases (Liana Technologies), social media updates and advertisements on both print and film, in addition to interviews given to different media. On social media, Tornio Brewery has generated content at an astonishing speed, often on a daily and at the very least on weekly basis. This material that contains more place-related storytelling than product data or investor-related information makes the brewery a rewarding subject for a case study. Moreover, while its beers receive mediocre scores on consumer-based rating sites like Ratebeer and Untappd, Tornio Brewery has decupled its turnover in three years. This success can be attributed to meditated and effective brand marketing.

\section{Research methods}

A mixed-method approach comprising traits of both content analysis and narrative analysis was applied on media content - the main body of which consists of comprises several hundred images and texts posted on social mediaput out by Tornio Brewery from the establishment of the company in early 2016 up till December 2019. The analysis involves the identification of those parts of the brand narrative that aim to construct, maintain and enhance the sense of place. The focus is on narrative patterns, the 
Fig. 1 Location map of Tornio and northern Finland. Adapted from a base map by Uwe Dedering (Wikimedia Commons, CC BY-SA 4.0)

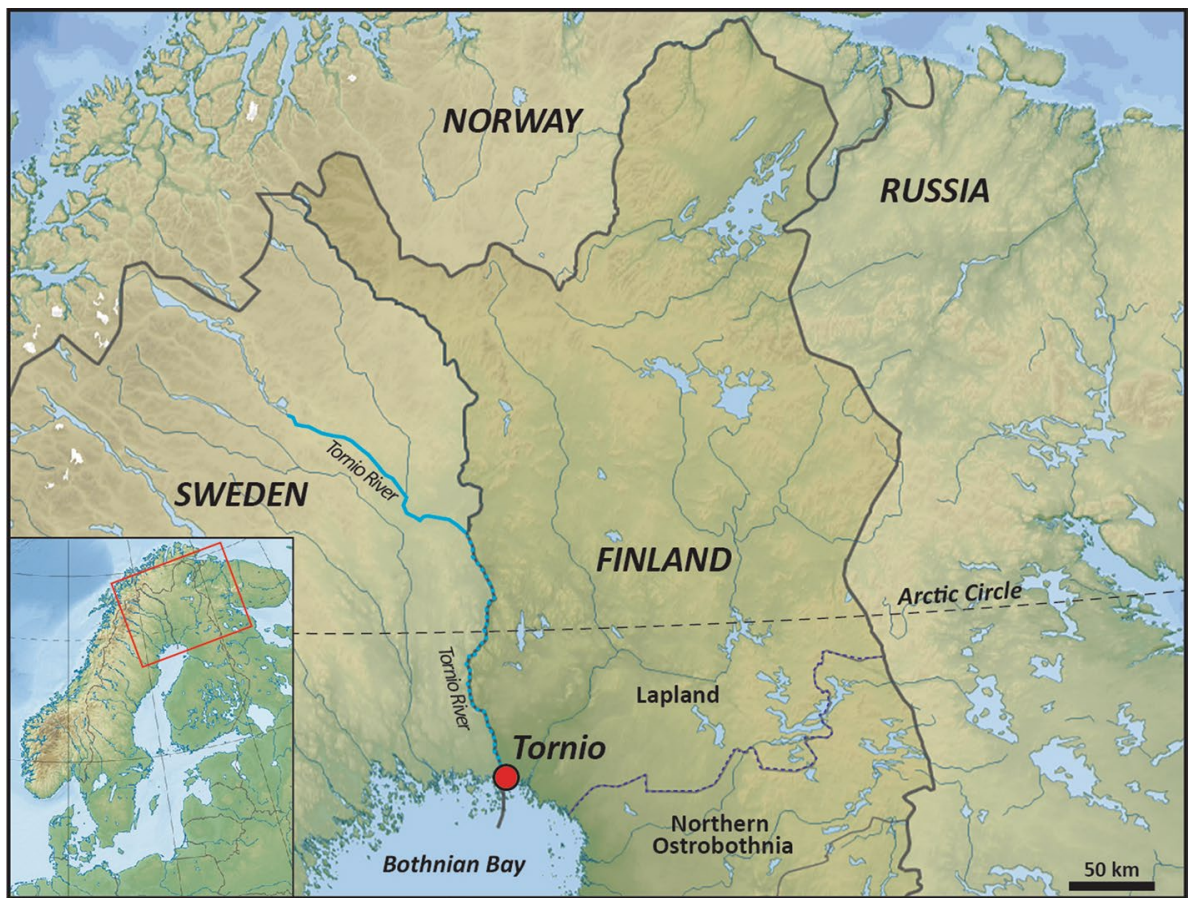

critical reading and deconstruction of which (see Boje 1995; Spear and Roper 2013) reveals the position of communicator to the recipients of the message as well as to the operating environment and the reasons behind them (Stern et al. 1998).

While the narrative content is mainly found in media releases, advertisements and other promotional material, the names and packaging of beers are also a relevant source of information, as the texts and images on the bottles or other packages are essential for the brand image in the beverage business. This material has been identified by juxtaposing it with the factual baseline established through other sources of information. These include but are not limited to the archives of Lapin Kulta Oy stored in the National Archives of Finland, as well as scholarly publications, newspaper and online articles focusing on subjects like the geography and history of northern Finland, as well as the history of brewing in Finland.

The application of this method resulted in a plethora of texts and images that can be recognized as vehicles of storytelling. Following the example of Boje (1995), the resulting material was arranged into thematic groups, which will be introduced next under four sub-headings: brewery history and heritage, Lapland and the Arctic as geographic locations, the use of local ingredients and community involvement, and the culture and heritage of northern Finland. The discussion that follows is begun with a chapter outlining the key constituents of the narrative-structural, functional, thematic and dialogic/performance- - before the implications of neolocal-influenced storytelling for brand marketing are discussed and potential future research topics are outlined.

\section{Results}

\section{History and heritage}

Tornio Brewery suggests that its corporate history extends back to 1873 (e.g., House of Lapland 2017a) when the first brewery in Tornio was founded by local officials and merchants as Torneå Bryggeri Aktiebolaget (Markkanen 1994). The connection is made explicit with the text "est. 1873" in its logo (Fig. 2), where the stylized tower is a visual reference to the period of 1958-1969 when the former brewery

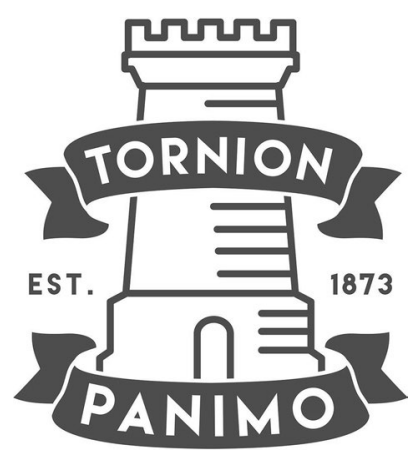

Fig. 2 Logo of Tornio Brewery. Reproduced by permission of Tornio Brewery 
operated at the site as Tornio Beer Inc. (fi. Tornion Olut Oy). The connection is highlighted also through material heritage on the brewery's website (Tornion Panimo 2016a), as "Tornion Panimo is ... still operating in the same place the brewery was built as far back as in 1873. Underneath our brewery lie the original, 140-year-old cellar vaults that will soon begin their new life as whiskey cellars." Yet, the only factual connection between the new brewery and its predecessor is the real estate on which it is located.

The brewery has also used history in form of retro brand marketing by reviving a beer first brewed at the premises over fifty years ago. The Original 1964 Lager beer (Fig. 3) is purportedly based on a recipe developed in the early $1960 \mathrm{~s}$ (Aula 2017a; Jylhänlehto 2017). The beer that was known back then as Lapin Kulta (Lapland's Gold) won a gold medal award at an international beer event in 1964 for its technical qualities (Markkanen 1994; Ikäheimo 2019). Paired with an aggressive marketing campaign in southern Finland, the award boosted its sales to the point that in 1969, the name of the brewery was changed to Lapin Kulta Oy (Teerijoki 2010). By the early 1990s, this beer held approximately $30 \%$ of the domestic beer market in Finland (Markkanen 1994; Teerijoki 2010), while Lapin Kulta Oy had simultaneously grown to be the biggest brewery unit in Finland and a very successful heritage brand (Ikäheimo 2019).

In this context, the former master brewer and CEO of Lapin Kulta, Leo Andelin, has been pushed into the limelight as the sole inventor of the recipe for the Lapin Kulta beer, while five people took part in its development (Ikäheimo 2019). Mr. Andelin, now in his early 80s, has also been referred to as Tornio Brewery's patron-mentor (Aula 2017b). Andelin's mentor status is also made explicit in a marketing film titled "The Return of the Fell
Streams," in which the former master brewer passes a symbolic torch from one generation to the next by proposing a toast to the new beginning with Kaj Kostiander, the current CEO of Tornio Brewery (Fig. 4).

The introductory text to the film reproduced under the heading "Our story" on the brewery's website (Tornion Panimo 2016b) informs the visitor (our translation): "It is a story about a brewery that has experienced years of prohibition, world wars, and a global strike that was meant to be lethal. Tornio Brewery is regarded as a symbol of Lappish resilience." The lethal strike is an obvious reference to developments that ultimately led to the closure of the brewery in Tornio in 2010. The rest of the story underlines the hardships experienced by the locals and the Finns in general, and their ability to overcome them.

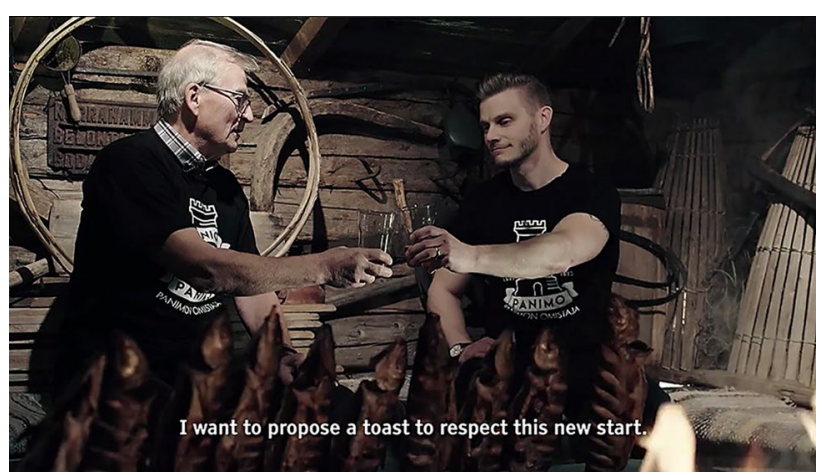

Fig. 4 A screenshot from the promotional film "The Return of the Fell Streams." Reproduced by permission of Tornio Brewery
Fig. 3 Original 1964 Lager beer can label. Reproduced by permission of Tornio Brewery

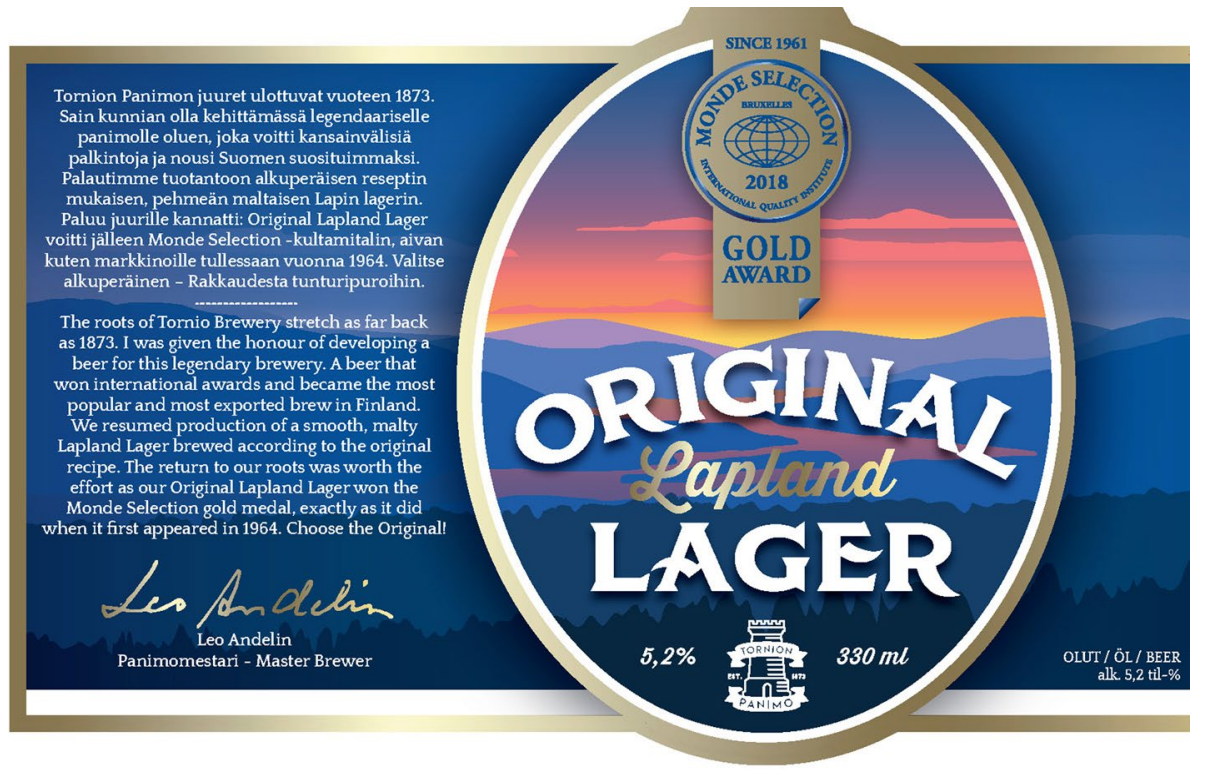




\section{Lapland and the Arctic}

The town of Tornio is administratively located in the most southwestern part of Finnish Lapland (Fig. 1), which lacks all aspects of topography, climate and vegetation considered typical of Lapland proper. The topography around Tornio is rather flat and featureless, with the closest fells located some $70 \mathrm{~km}$ north of the town. Climatically, the area belongs to the Middle Boreal zone with coniferous forests representing the western fringes of the vast Eurasian taiga. Yet, in some definitions issued by entities like the Arctic Council and the Government of Finland, the whole area of the modern administrative region of Lapland belongs to the Arctic (e.g., Arctic Portal 2016).

For businesses located in the southern fringes of this area, the decision offers a multitude of possibilities related both to the name Arctic and to the images and myths that open up via this association. The northernmost area in Finland is characterized by remoteness and extreme nature, including the midnight sun in the summer and the northern lights in the winter, as well as by the Sámi, its indigenous inhabitants. All these features have contributed to the image of Lapland as an exotic and mythical enchanted land (see, e.g., Herva and Lahelma 2019). It has therefore been profitable for Tornio Brewery to define itself as a "brewery in the Arctic" (House of Lapland 2017a) and to use the word "Arctic" as a name for one of its four product lines (Fig. 5). The other three are named with similarly north-associated words "North," "Lapland" and "Thule"the farthest north location mentioned in ancient Greek and Roman literature.

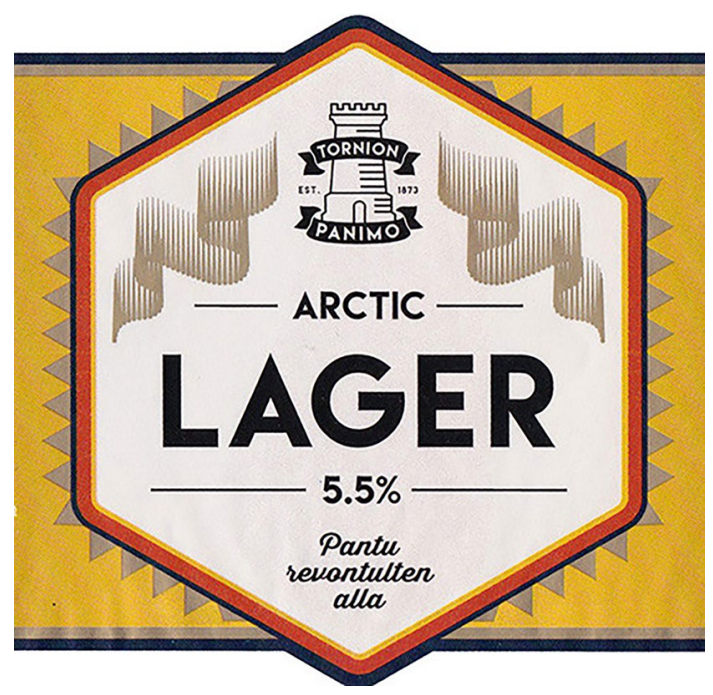

Fig. 5 Arctic Lager beer bottle label. Reproduced by permission of Tornio Brewery
Yet, the brewery has been surprisingly modest with the use of images related to the geographic Arctic. Instead, the main body of its marketing imagery, product labeling included (Fig. 3), is either derived from or at least seeks to invoke ideas of the Tornio River. The choice is quite natural, as the brewery and the historic center of Tornio are located on Suensaari Island by the estuary of the Tornio River, which has always been important for the town, both as a waterway to the north and as a source of income due to the abundance of salmon and other fish. The connection to the river is emphasized even in small details. For example, the meeting between the master brewer Andelin and CEO Kostiander is cleverly set in a log shed (Fig. 4), with traps and traditional fishing equipment decorating the walls and a bunch of whitefish being planked by the fire on the foreground.

Due to its location (ca. $65^{\circ} 50^{\prime} 33^{\prime \prime}$ ) at a sufficiently high latitude, the town of Tornio occasionally experiences the northern lights (aurora borealis) that result from disturbances in the Earth's magnetosphere induced by the solar wind. Quite predictably, this wondrous natural phenomenon has been incorporated into Tornio Brewery's marketing agenda. It is epitomized with "Brewed under the northern lights"- slogan printed on the labels of all beers in "Arctic"-series while stylized northern lights border the company logo in them (Fig. 5). While people outside northern Europe cannot necessarily decipher these symbols, they constitute a unifying neutral element for those living within their sphere of influence.

\section{Local ingredients and community involvement}

Tornio Brewery has promoted the mental image of the use of local ingredients from the beginning (Sangen 2016) by stating that all the basic ingredients of brewing - grains, yeast, hops and water-would someday be derived from local sources. Instead of coming from the brewery's laboratory, as originally planned, brewing yeasts are still purchased from abroad, and Viking Malt, a malting house supplying nearly all Finnish craft breweries, is the main source for malted barley. Yet, the brewery has announced plans for a malting house that should be in operation by 2021 (Murtovaara 2019). In the meantime, some barley used as a supplemental grain for Arctic Stout together with some natural flavoring agents like hemp, cloudberries, and lingonberries used in the production of other beers come from providers located in northern Finland (House of Lapland 2017a; Jylhänlehto 2017; Tornion Panimo 2017).

Good water has always been essential for the reputation of a beer, although sometimes the reputation relies more on effective marketing lore than on its actual quality (Eberts 2014; Gatrell et al. 2014). When Lapin Kulta was introduced in the early 1960s, the beer was marketed as a 
symbol of freshness and purity with a slogan inspired by unspoiled crystal-clear fell streams: "A step ahead with Lappish water." This was soon changed into the more figurative motto "The freshness of the fell streams" (Markkanen 1994; Ikäheimo 2019). Tornio Brewery has both paraphrased it into "For the love of fell streams" and rephrased it as (our translation):"According to researchers, $90 \%$ of the water in the Tornio River comes from the fell streams of Lapland." (Sangen 2016).

The validity of the claim is of secondary importance because Tornio Brewery does not use water extracted from the Tornio River like its predecessor (Pesonen and Könönen 1973) due to its inconsistent quality (Jylhänlehto 2017). Instead, the brewery uses local groundwater (House of Lapland 2017b; Tornion Panimo 2017) distributed by the Tornio waterworks. But together with images of a free-flowing river on beer labels (Fig. 3), the positive geo-psychological impact (see Gatrell et al. 2014) on consumers may be considerable. To create another water-related product with a local twist, the brewery has launched a beer named Perämeri Gose-a gose is a German-style beer getting its saline taste from added salt. With the addition of sea salt, this product has purportedly the same salinity as the Bothnian Bay (fi. Perämeri) in the early spring.

Although Tornio Brewery currently uses mainly imported hops, it has aimed from the beginning to revive hop varieties that were grown locally before cultivation ceased in the early twentieth century as great quantities of cheap hops were imported from Central Europe (Bitz 2017). These relic hop species preserved in the wild, chiefly near old farmsteads, have only recently become the focus of commercial and scientific interest. A systematic survey of native Finnish hops has recently been undertaken by the Natural Resources Institute Finland (Bitz 2017).

In October 2017, Tornio Brewery launched a one-time seasonal brew named Arctic Hops with a reference to the use of the northernmost-grown hops in the world (Sallinen
2017). The connection with the past was underlined by Mr. Jami Teirikari, the marketing director of Tornio Brewery (our translation): "the taste of this new release can be traced back to the harvests of the early mother vines in the golden age of hop cultivation. Maybe some imagination is needed when you travel through the centuries to the reign of Charles XI" (of Sweden, 1655-1697) (Olutpostimestari 2017). In May 2018, plans were announced to cultivate hops in the abandoned Pyhäsalmi copper and zinc mine $660 \mathrm{~m}$ below the ground surface (Uusitalo 2018). While the pilot experiment was an apparent success (Määttä 2018), this did not lead to actual hop production.

Tornio Brewery's community involvement (see, e.g., Graefe et al. 2017) has taken many forms. Keep Lapland Tidy Association has been promised a fixed sum for every sale of North Arctic Lager (Hyttinen 2017). Mash leftovers from the brewing process are used for fodder at a nearby wild boar farm (Hyttinen 2017; Jylhänlehto 2017). The economic involvement with the local community has also taken more money-intensive forms, as the recently installed and fully automated production line offering higher production capacity was made of stainless steel produced by the local Outokumpu steelworks (Koskinen 2016).

\section{Culture and heritage}

While links to local culture and heritage are often valued at least as much as the use of local ingredients in establishing the feeling of localness (e.g., Schnell and Reese 2014), Tornio Brewery has explored this possibility quite sparingly. The reason for this may be a conscious choice to avoid conflicts with the Sámi, the first nation and culture of northern Fennoscandia and northwest Russia, which has a long and unfortunate history of exploitation (Lehtola 2015). Only the label of North Arctic Lager (Fig. 6) and two other beers in the brewery's North-series contain a possible yet not an
Fig. 6 North Arctic Lager beer bottle label. Reproduced by permission of Tornio Brewery

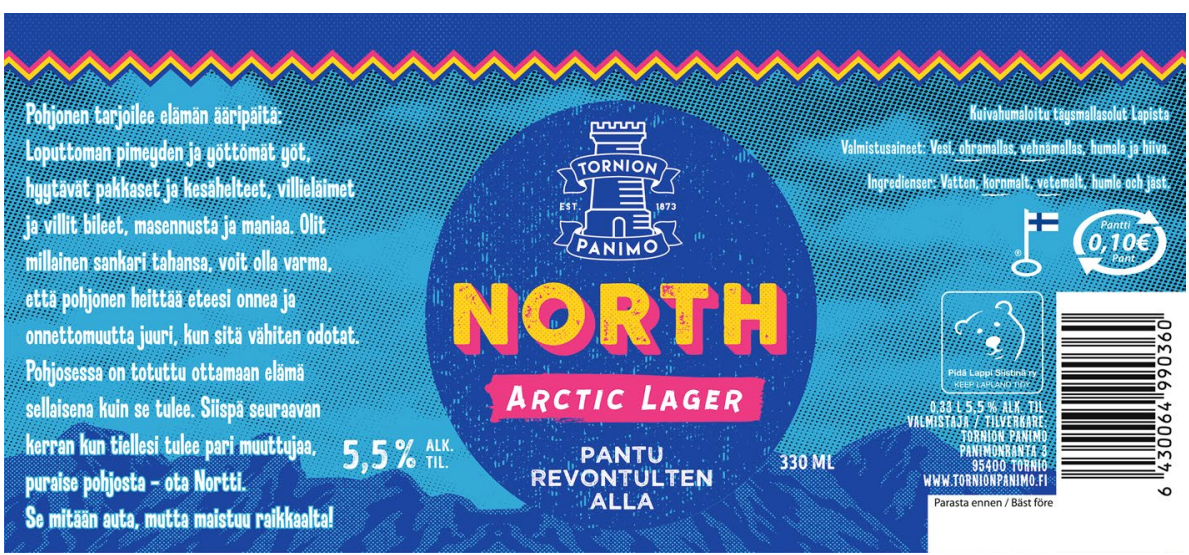


overtly apparent reference to the Sámi culture in the form of a tricolor sawtooth pattern decorating its upper edge. In Scandinavia, the pattern is a commonly recognized and widely used reference to the northern lights, a motif of Sámi origin that is also used by some regional groups of Sámi in their national dress. The motif is used in this label together with a pale blue base color and a crest of mountaintops-a geographical feature highly atypical of southern Lapland, intended as a reference to the extreme north.

While previously found to be effective in attaching a brand to a place (Hede and Watne 2013), the utilization of local tales and heroes by the brewery has been limited to the name and imagery associated with Mustaparran Terva Stout (Blackbeard's Tar Stout; Fig. 7). The tale of Iisakki Mustaparta_in real life a peasant named Isak Moding - is the story of a semi-fictional clandestine sea merchant and pirate of the late eighteenth century. As told by Olof Hederyd in his 1989 novel Isak Mustaparta-Bottenvikspiraten, this "local Robin Hood" opposed the foreign trade monopoly held by the burghers of Tornio by building a seafaring ship and sailing it loaded with wood tar to Stockholm. Thus, the beer has been flavored with wood tar extract, which has a very strong local association. Wood tar was among the main exports of northern Finland before the early twentieth century, as it was customarily applied to ships and sails for waterproofing (e.g., Kunnas 2007).

However, the brewery reached the pinnacle of culture and heritage -related storytelling in 2017, when Finland celebrated its centenary of national independence. A short film titled "Industry and labor as builders of welfare" (3:06), presenting the country's industrial development during the past hundred years in tightly cut short clips mixing slogans with documentary shots of historical events and industrial milestones, was posted to Tornio Brewery's Facebook page three days before the Independence Day. It was accompanied

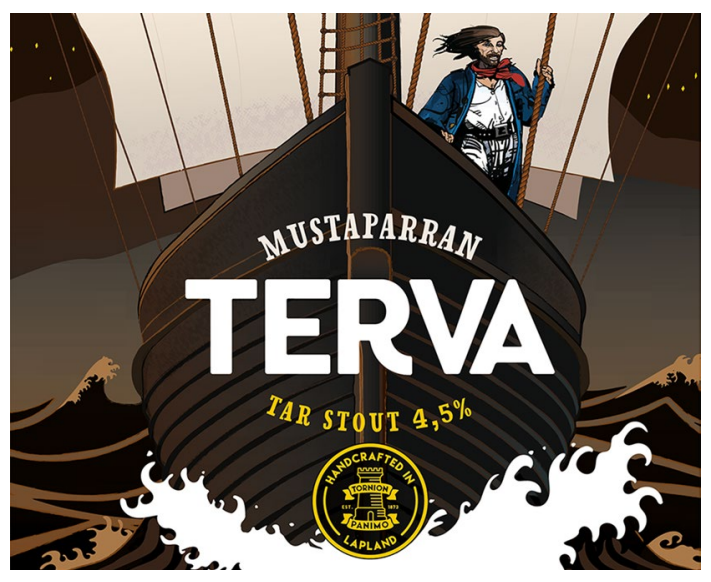

Fig. 7 Mustaparran Terva Stout (Blackbeard's Tar Stout) beer bottle label. Reproduced by permission of Tornio Brewery with the comment (our translation): “... In Tornio we tip our hats also because our humble brewery has been elevated to such grand company."

In the film's narrative (02:18-02:24), Tornio Brewery is assimilated into the country's industrial heritage (see Banerjee 2008; Hakala et al. 2011) and presented as a potential vanguard corporation of the future. The respective sequence culminates in the appearance of the brewery logo at the end. Two facts explain this somewhat surprising twist. Firstly, the film was directed by Jami Teirikari-a board member of the film's producer Pohjantähti-Elokuva Oy (Polestar Films Inc.) - who also acts as the marketing director of Tornio Brewery. Secondly, the version uploaded to social media had been edited to include the segment on Tornio Brewery, whereas this imagery is absent from the official version of the short film.

\section{Discussion}

\section{Case-specific observations}

The principal theme of Tornio Brewery's storytelling is a survivor narrative or a heroic tale following an archetypal storyline and containing archetypal characters (see Megehee and Woodside 2010). Structured as a thematic story, it follows quite closely a dramatic arc or an emotional slope (Woodside et al. 2008), about a local yet very successful brewery that is first taken over by its domestic rival. Soon thereafter, the local community is "betrayed" for the second time as the brewery is sold to an international corporate, which decides to close it down. This turning point of the story followed by a short hiatus sets the stage for the arrival of a knight in shiny armor (Tornio Brewery). An old wizard (master brewer Andelin) helps the knight to save the princess (Original 1964 Lager) and to restore the state of equilibrium in the local community through his just actions (Kniazeva and Belk 2007, see also Holt 2004; Beckham 2017).

The narrative put out by Tornio Brewery also posits the brand person in several recognizable roles-the rebel, the champion and the underdog (see Herskovitz and Crystal 2010) - making the story easier to tell and to digest. The rebellious "us vs. them" rhetoric has been used for long by the craft beer community, as well as other businesses (see, e.g., Kniazeva and Belk 2007; Hsu et al. 2009; Beckham 2017). Here, the outcome is a brand story (see Maguire et al. 2017) about an artisanal brewery with long traditions that is constantly fighting the global profit-oriented beverage business with a punk attitude. The restitution of a brewery in Tornio can therefore be told as a story of just revenge, or, as the brewery somewhat vulgarly formulates it: "We at Tornion Panimo make a bow to our long traditions and bare 
our behind to global giants. Here we still are, and there's nothing you can do about it!" (Tornion Panimo 2016b).

As the closure of the brewery in 2010 had traumatized the local society, the "re-launch" of the brewery with the re-introduction of its former flagship beer utilized communal nostalgia (see Brown et al. 2003; Balmer and Burghausen 2015; and also Kniazeva and Belk 2007; Rose et al. 2016). Back in the good old days, the brewery had churned a profit for the common good and the sweet smell of mashed malt filled the air (see also Wiedmann et al. 2011; Schnell 2013; Schnell and Reese 2014; Thurnell-Read 2019). The inhabitants of northern Finland and especially the people of Tornio were now offered a chance to reclaim the future into their own hands by investing in Tornio Brewery through two share issues based on crowdfunding platforms. The restitution became a question of local pride (see also Flack 1997); even a regional flag day was proposed to celebrate the day of the brewery's relaunch (Koskinen 2016).

The opening of the new brewery within the former real estate of the Lapin Kulta brewery was essential, as it offered a strong material presence embodied in the townscape of Tornio. This benefited the corporate heritage identity (see Spielmann et al. 2019) and was crucial for geographical authenticity (Thurnell-Read 2019). Tornio Brewery was instantly a place-based brand (see Taylor Jr and DiPietro 2020) when it assimilated existing place and corporate heritage as marketing and consumption resources into its own corporate identity (see Balmer and Burghausen 2019; Spielmann et al. 2019).

The instantly established corporate provenance with cultural belonging (see Burghausen and Balmer 2014b) has enabled storytelling related to a place with history (see Hede and Watne 2013). The use of the year 1873 in the $\log$, the restitution of the former flagship beer as Original 1964 lager as well as the reference to 140-year-old cellar vaults serve as good, but not unique examples (see Pizzi and Scarpi 2019; Spielmann et al. 2019) of such endeavors. Both Lapin Kulta's history and brand heritage were thus turned into a strategic resource to invoke vicarious nostalgia (Merchant and Rose 2013; Rose et al. 2016) and socially shared corporate memories (Balmer and Burghausen 2015) through visual and textual cues put out in social media and other advertising. In this way, Tornio Brewery has created a brand persona, whose constant messaging aims at attracting and sustaining the interest of consumers (see Stern 1994).

The names and labels of Tornio Brewery's beers refer to "unspoiled landscapes" (see also Schnell and Reese 2003, 2014). They are both sufficiently generic and yet specific enough to further amplify the credibility of claims about the enhanced sense of place. The use of the local ingredients serves the same purpose showing that brewers know the right place and moment to source them or, at least, their local production is included in the plans for the future. All these demonstrations of neolocalism, including community involvement, are needed to show how deeply embedded the operations of the brewery are rooted in local and domestic history.

Thus, the main function of the stories told by Tornio Brewery is to gain at least the position of a legitimate successor, if not completely assimilate the new business venture with its predecessor. Here, the double status of the former master brewer Leo Andelin as the "inventor" of the flagship beer and the mentor of the new brewery is essential as the critical cultural intermediary for enhanced biographical authenticity (see Thurnell-Read 2019). The identity at stake is Tornio Brewery's credibility as a (neo)local enterprise, and in this quest, the local brewing history is an invaluable asset. Therefore, narratives are mainly told to local and domestic audiences already acquainted with the imagery used and may also be, to a varying degree, aware of their background. For a foreign clientele, marketing texts and images offer glimpses to the exotic and enchanted Lapland.

"Storytelling brewery" (Pulizzi 2012) is probably the best definition of what Tornio Brewery does. It produces beers with accompanying stories about the beers and their brewers (Aula 2017b), seeking to empower the domestic buyer with feelings of uniqueness and localness. The extensive and clever utilization of tales, narratives, myths and "brand poetics" (for the definition, see, e.g., Urde et al. 2007; Hede and Watne 2013) has turned it into a socially situated brand (Muniz and O'Guinn 2001) that is attached to a place. All the essential elements of brand history-people, town, and the country as well as important events (Dion and Mazzalovo 2016) - have been successfully incorporated into its narrative (e.g., Flack 1997; Urde et al. 2007; Rose et al. 2016).

Overstatement and explicit commentary can be proactively used to signify fictional authenticity claims, but the narrative put out by Tornio Brewery does not seem to contain proverbial "winks" for consumers to identify these stories as advertising (see O'Neill et al. 2014). While craftsmanship, naturalness, concrete locations and historical roots have been identified as the four strategies of authentication (O'Neill et al. 2014), their closer examination has revealed them here as intentional marketing lore rather than realitybased claims. This brings us to the wider implications of this case.

\section{Wider implications}

At first, it must be stressed that as Tornio Brewery operates in a specific geographic context, its story is difficult to replicate per se elsewhere. However, its main component-active storytelling rooted in the neolocal narrative(s) — should be transferable to nearly any environment under certain preconditions. From the perspective of brand marketing, the need for meditated yet reactive planning and the continuous 
monitoring of the operational environment might be the most important of them, as the results strengthen the argument about the significance of context variables to the building and exploitation of concepts like neolocalism and terroir (see Riviezzo et al. 2017).

While the passion for the craft instead of the profit is believed to distinguish microbreweries from bigger brewing enterprises (Maguire et al. 2017), this should not imply the categorical exclusion of marketing professionals from their operations. Quite the reverse, the current case underscores the importance of a marketing director with suitable business curricula (Herskovitz and Crystal 2010) to oversee and co-ordinate that various threads of the narrative form a coherent entity, a story. As the story needs to be holistic and meditated to be credible, it needs to be reflexive. Therefore, the results stress the importance of social media as a marketing palimpsest for narratives that can be created quickly, adjusted when necessary and virally shared from consumer to consumer when the content is found to be interesting or amusing enough (Herskovitz and Crystal 2010; Smith 2011; Sjölander-Lindqvist et al. 2019).

The results also confirm the effectiveness of emotional elements that elevate narratives containing merely sequences of events with chronological and causal links to proper stories (Spear and Roper 2013). For example, oppositional authenticity is both an effective and affective way to gain local support (see Thurnell-Read 2019). In the present case, the identification of a common enemy for this purpose was not particularly difficult for the new entrepreneurs, as the previous company takeover executed by a multinational company had ended with discouraging results. Such an unpleasant memory can be erased, if there are authentic locations with associated heritage to be adopted or even appropriated (Lamertz et al. 2016) as visual or verbal branding elements (Wilson 2018). And when brand heritage is stressed vigorously enough, neolocal storytelling may reach a point at which it turns into self-definition as a heritage brand (see Urde et al. 2007). Thus, as repeatedly pointed out, heritage is not only relevant for the brand at present, but also a potential positive asset for the future (e.g., Bessière 1998; Urde et al. 2007; Balmer and Burghausen 2015).

As holistic product identity created through territorial brand management decisions is obviously of great importance (Melewar and Skinner 2020) for geographical authenticity (Schnell and Reese 2003; Beverland et al. 2008; Thurnell-Read 2019), the message about the rootedness to a place (see Banerjee 2008) should be determinedly conveyed and repeated on every possible occasion. Yet, the present study has repeatedly shown that authenticity is not an absolute precondition for enhancing the sense of place (cf. Chiu et al. 2021). Creating an exaggerated image of the neolocal that is backed up by little or no substance at all may be despised as the bastardization of neolocalism (Eberts 2014), but one has to agree with O'Neill et al. (2014) that their very existence is rooted in cultural craving of authenticity myths. With skillful brand marketing, even a vast geographic area like the Arctic can be turned into a manifestation of "origin" and "rootedness" for enhanced place relatedness.

From the methodological point of view, this paper has for its part validated the use of qualitative research methods as a viable way to study neolocalism and storytelling in brand marketing. While expressions of neolocal have and can be approached quantitatively, qualitative analysis has its merits in the identification and analysis of these expressions. Therefore, it offers a different but potentially also a richer source of information regarding this phenomenon, which is of growing importance in brand marketing.

As expressions of neolocalism are bound to specific spatio-temporal contexts, more research that considers both variables will be needed in the future, particularly outside the Anglosphere. For example, the case published by Melewar and Skinner (2020) on a Corfiot microbrewery that uses history and heritage to evoke the sense of place as a brand management strategy is roughly similar yet still different to the one laid out in preceding pages. This further strengthens the argument about the validity of in-depth case studies related to concepts of neolocalism and terroir, although their generalizability may be somewhat limited. Yet, it is the way to put local in neolocal and localized neolocal in brand marketing.

\section{Conclusions}

The results of the present case study focusing on a relatively new microbrewery operating in northern Finland within the same premises as the former brewing giant indicate that the sense of place, in other words, neolocalism, can be enhanced with a solid narrative that incorporates but is not limited to history, heritage, geography and local resources. Together, they provide a rich vein of storytelling that can be used effectively for brand marketing purposes as a holistic concept. A reflexive narrative can also be modified to contain new territory associations for more profound and wider geographic reach. In the post-industrial or post-modern consumer economy, such narratives and the ways they are told are often enough to enhance not only the sense of place, but also authenticity and familiarity, thus strengthening the overall consumer experience.

Funding Open Access funding provided by University of Oulu including Oulu University Hospital. 


\section{Compliance with ethical standards}

Conflict of interest The author declares that he has no conflict of interest.

Open Access This article is licensed under a Creative Commons Attribution 4.0 International License, which permits use, sharing, adaptation, distribution and reproduction in any medium or format, as long as you give appropriate credit to the original author(s) and the source, provide a link to the Creative Commons licence, and indicate if changes were made. The images or other third party material in this article are included in the article's Creative Commons licence, unless indicated otherwise in a credit line to the material. If material is not included in the article's Creative Commons licence and your intended use is not permitted by statutory regulation or exceeds the permitted use, you will need to obtain permission directly from the copyright holder. To view a copy of this licence, visit http://creativecommons.org/licenses/by/4.0/.

\section{References}

Arctic Portal. 2016. Maps: arctic definitions. https://arcticportal.org/ maps-arctic-definitions. Accessed 29 Aug 2019.

Aula, M. 2017a. Kulta-olut palautettiin Tornioon - resepti löytyi entisen panimomestarin muistiinpanoista [Gold beer was returned to Tornio - the recipe was found among the notes of the former master brewer; online]. https://yle.fi/uutiset/3-9604572. Accessed 29 Aug 2019.

Aula, M. 2017b. Oluen panemisessa tarvitaan edelleen käsityöläistaitoa - Suomessa on kuitenkin vain kourallinen panimomestareita [Craft skills are still required in brewing-Finland has only a handful of master brewers; online]. http://yle.fi/uutiset/3-96031 59. Accessed 29 Aug 2019.

Balmer, J.M.T., and M. Burghausen. 2015. Explicating corporate heritage, corporate heritage brands and organisational heritage. Journal of Brand Management 22(5): 364-384.

Balmer, J.M.T., and M. Burghausen. 2019. Marketing, the past and corporate heritage. Marketing Theory 19(2): 217-227.

Banerjee, S. 2008. Strategic brand-culture fit: A conceptual framework for brand management. Journal of Brand Management 15(5): 312-321.

Barker, R.T., and K. Gower. 2010. Strategic application of storytelling in organizations. Toward effective communication in a diverse world. Journal of Business Communication 47(3): 295-312.

Beckham, J.N. 2017. Entrepreneurial leisure and the microbrew revolution: The neoliberal origins of the craft beer movement. In Untapped: Exploring the Cultural Dimensions of Craft Beer, ed. N.G. Chapman, J.S. Lellock, and C.D. Lippard, 80-101. Morgantown: West Virginia University Press.

Belmartino, A., and N. Liseras. 2020. The craft beer market in Argentina: An exploratory study of local brewers' and consumers' perceptions in Mar del Plata. Papers in Applied Geography. https:// doi.org/10.1080/23754931.2020.1747525.

Bessière, J. 1998. Local development and heritage: Traditional food and cuisine as tourist attractions in rural areas. Sociologia Ruralis 38(1): 21-34.

Beverland, M.B., A. Lindgreen, and M.W. Vink. 2008. Projecting authenticity through advertising: Consumer judgments of advertisers' claims. Journal of Advertising 37(1): 5-15.

Bitz, L. 2017. Hunting Finnish hops [online]. https://www.luke.fi/blogi /hunting-finnish-hops-2. Accessed 29 Aug 2019.
Boje, D.M. 1995. Stories of the storytelling organization: A postmodern analysis of Disney as Tamara-Land. Academy of Management Journal 38(4): 997-1035.

Boutlis, P. 2000. A theory of postmodern advertising. International Journal of Advertising: The Review of Marketing Communications 19(1): 3-23.

Brown, S., R. Kozinets, and J.F. Sherry Jr. 2003. Teaching old brands new tricks: Retro branding and the revival of brand meaning. Journal of Marketing 67(3): 19-33.

Brunninge, O., and B.J. Hartmann. 2019. Inventing a past: Corporate heritage as dialectical relationships of past and present. Marketing Theory 19(2): 229-234.

Buchanan, D.A. 1999. The logic of political action: An experiment with the epistemology of the particular. British Journal of Management 10 (3 spec. iss.): S73-S88.

Burghausen, M., and J.M.T. Balmer. 2014. Corporate heritage identity management and the multi-modal implementation of a corporate heritage identity. Journal of Business Research 67(11): 2311-2323.

Burghausen, M., and J.M.T. Balmer. 2014. Repertoires of the corporate past: Explanation and framework: Introducing an integrated and dynamic perspective. Corporate Communications: An International Journal 19(4): 384-402.

Chiu, H.C., Y.C. Hsieh, and Y.C. Kuo. 2012. How to align your brand stories with your products. Journal of Retailing 88(2): 262-275.

Debies-Carl, J.S. 2019. Beyond the local: Places, people, and brands in New England beer marketing. Journal of Cultural Geography 36(1): 78-110.

Dion, D., and G. Mazzalovo. 2016. Reviving sleeping beauty brands by rearticulating brand heritage. Journal of Business Research 69(12): 5894-5900.

Eberts, D. 2014. Neolocalism and the branding and marketing of place by Canadian microbreweries. In The Geography of Beer: Regions, Environment, and Societies, ed. M. Patterson and N. Hoalst-Pullen, 189-199. Dordrecht: Springer Netherlands.

Escalas, E. 2004. Narrative processing: Building consumer connections to brands. Journal of Consumer Psychology 14(1 \& 2): 168-179.

Firat, A.F., and A. Venkatesh. 1993. Postmodernity: The age of marketing. International Journal of Research in Marketing 10(3): 227-249.

Flack, W. 1997. American microbreweries and neolocalism: "Ale-ing" for a sense of place. Journal of Cultural Geography 16(2): 37-53.

Fletchall, A.M. 2016. Place-making through beer-drinking: A case study of Montana's craft breweries. Geographical Review 106: 539-566.

Fog, K., C. Budtz, and B. Yakaboylu. 2005. Storytelling-Branding in Practice. Berlin: Springer.

Garavaglia, C. 2020. The emergence of Italian craft breweries and the development of their local identity. In The Geography of Beer: Culture and Economics, ed. N. Hoalst-Pullen and M. Patterson, 167-187. Cham: Springer Nature.

Gatrell, J.D., D.J. Nemeth, and C.D. Yeager. 2014. Sweetwater, mountain springs, and great lakes: A hydro-geography of beer brands. In The Geography of Beer: Regions, Environment, and Societies, ed. M. Patterson and N. Hoalst-Pullen, 89-98. Dordrecht: Springer Netherlands.

Graefe, D., A. Mowen, and A. Graefe. 2017. Craft beer enthusiasts' support for neolocalism and environmental causes. In Craft Beverages and Tourism, Volume 2: Environmental, Societal, and Marketing Implications, ed. S. Slocum, C. Kline, and C. Cavaliere, 27-47. Cham: Palgrave Macmillan.

Hakala, U., S. Lätti, and B. Sandberg. 2011. Operationalising brand heritage and cultural heritage. Journal of Product \& Brand Management 20(6): 447-456. 
Hede, A.-M., and T. Watne. 2013. Leveraging the human side of the brand using a sense of place: Case studies of craft breweries. Journal of Marketing Management 29(1-2): 207-224.

Herskovitz, S., and M. Crystal. 2010. The essential brand persona: Storytelling and branding. Journal of Business Strategy 31(3): 21-28.

Herva, V.-P., and A. Lahelma. 2019. Northern Archaeology and Cosmology: A Relational View. Abingdon: Routledge.

Holt, D.B. 2004. How Brands Become Icons. The Principles of Cultural Branding. Boston, MA: Harvard Business School Press.

Holtkamp, C., T. Shelton, G. Daly, C.C. Hiner, and R.R. Hagelman III. 2016. Assessing neolocalism in microbreweries. Papers in Applied Geography 2(1): 66-78.

House of Lapland. 2017a. Tornion Panimo-A brewery with a long and rich tradition [online]. https://www.lapland.fi/business/compa ny/tornion-panimo-brewery-long-rich-tradition/. Accessed 29 Aug 2019.

House of Lapland. 2017b. The northern products of Tornion Panimo. https://www.lapland.fi/solution/the-northern-products-of-tornionpanimo/. Accessed 29 Aug 2019.

Hsu, S.-Y., N. Dehuang, and A.G. Woodside. 2009. Storytelling research of consumers' self-reports of urban tourism experiences in China. Journal of Business Research 62(12): 1223-1254.

Hyttinen, J. 2017. Tornion Panimo kampanjoi ympäristön puolesta [Tornio Brewery campaigns for the environment; online]. https ://olutposti.fi/tornion-panimo-kampanjoi-ympariston-puolesta/. Accessed 4 Jan 2018

Ikäheimo, J. 2019. The freshness of the fell streams: Contextualizing the success of Lapin Kulta Beer in the 1960s. Journal of Historical Research in Marketing 11(2): 165-180.

Jones, E. 2017. Brewing green: Sustainability in the craft beer movement. In Craft Beverages and Tourism, Volume 2: Environmental, Societal, and Marketing Implications, ed. S. Slocum, C. Kline, and C. Cavaliere, 9-26. Cham: Palgrave Macmillan.

Jylhänlehto, S. 2017. Tornionjoen äärellä kypsyy taas tutunmakuinen olut, a beer with familiar taste is brewing again by the Tornio River; online. http://www.maaseuduntulevaisuus.fi/talous/torni onjoen-\%C3\%A4\%C3\%A4rell\%C3\%A4-kypsyy-taas-tutunmakui nen-olut-1.196694. Accessed 29 Aug 2019.

Kaufman, B. 2003. Stories that sell, stories that tell. Journal of Business Strategy 24(2): 11-15.

Kniazeva, M., and R.W. Belk. 2007. Packaging as vehicle for mythologizing the brand. Consumption Markets \& Culture 10(1): 51-69.

Koskinen, R. 2016. Tornion Panimo laajentaa 1,5 miljoonalla tehtaaseen täysin automatisoitu tuotantolinja [Tornio Brewery is expanding with 1.5 millions - the factory gets a fully automated production line; online]. https://yle.fi/uutiset/3-9179037. Accessed 29 Aug 2019.

Kunnas, J. 2007. Potash, saltpeter and tar. Production, exports and use of wood in Finland in the 19th century. Scandinavian Journal of History 32(3): 281-311.

Lamertz, K., W.M. Foster, D.M. Coraiola, and J. Kroezen. 2016. New identities from remnants of the past: an examination of the history of beer brewing in Ontario and the recent emergence of craft breweries. Business History 58(5): 796-828.

Lehtola, V.-P. 2015. Sámi histories, colonialism, and Finland. Arctic Anthropology 52(2): 22-36.

Liana Technologies. s.a. Press release success story for Tornio Brewery [online]. https://www.lianatech.com/customer-stories/press -releases.html. Accessed 29 Aug 2019.

Lundqvist, A., V. Liljander, J. Gummerus, and A. van Riel. 2013. The impact of storytelling on the consumer brand experience: The case of a firm-originated story. Journal of Brand Management 20(4): 283-297.

Määttä, M. 2018. Humala kasvaa Pyhäsalmen kaivoksessa 660 metrin syvyydessä - maan alla vuodenajalla tai vuorokaudenajalla ei ole väliä [Hops are grown in the Pyhäsalmi mine at the depth of 660 meters - season or the time of the day do not matter under ground; online]. https://www.kaleva.fi/uutiset/pohjo is-suomi/humala-kasvaa-pyhasalmen-kaivoksessa-660-metri n-syvyydessa-maan-alla-vuodenajalla-tai-vuorokaudenajallaei-ole-valia/805529/. Accessed 20 Dec 2019.

Maguire, J.S., J. Bain, A. Davies, and M. Touri. 2017. Storytelling and market formation: An exploration of craft brewers in the UK. In Untapped: Exploring the Cultural Dimensions of Craft Beer, ed. N.G. Chapman, J.S. Lellock, and C.D. Lippard, 19-38. Morgantown: West Virginia University Press.

Markkanen, E. 1994. Lapin Kulta- läänin vanhin teollisuuslaitos [Lapin Kulta - the oldest factory in the province]. Tornionlaakson vuosikirja 1994: 155-160.

Megehee, C.M., and A.G. Woodside. 2010. Creating visual narrative art for decoding stories that consumers and brands tell. Psychology and Marketing 27(6): 603-622.

Melewar, T.C., and H. Skinner. 2020. Territorial brand management: Beer, authenticity, and sense of place. Journal of Business Research 116: 680-689.

Merchant, A., and G.M. Rose. 2013. Effects of advertising-evoked vicarious nostalgia on brand heritage. Journal of Business Research 66(12): 2619-2625.

Muniz, A.M., Jr., and T.C. O'Guinn. 2001. Brand community. Journal of Consumer Research 27(4): 412-432.

Murtovaara, H. 2019. Ouluun halutaan rakentaa maailman pohjoisin mallastamo, hankkeelle haetaan rahoittajia: "Tarvitaan paikallista mallasta, paikallista humalaa ja paikallista hiivaa" [Plans for the world's northernmost malting house are announced, investors are sought: "Local malts, local hops and local yeast are needed"; online]. https://www.kaleva.fi/uutiset/oulu/ouluu n-halutaan-rakentaa-maailman-pohjoisin-mallastamo-hankk eelle-haetaan-rahoittajia-tarvitaan-paikallista-mallasta-paika 1lista-humalaa-ja-paikallista-hiivaa/825503/. Accessed 21 Dec 2019.

O'Brien, J. 2020. The branding geography of Surrey craft breweries. In The Geography of Beer: Culture and Economics, ed. N. HoalstPullen and M. Patterson, 23-33. Springer Nature: Switzerland.

O’Neill, C., D. Houtman, and S. Aupers. 2014. Advertising real beer: Authenticity claims beyond truth and falsity. European Journal of Cultural Studies 17(5): 585-601.

Olutpostimestari. 2017. Maailman pohjoisin humala pääsi olueen. [World's northernmost hops used to brew beer; online]. https:// olutposti.fi/maailman-pohjoisin-humala-paasi-olueen/. Accessed 29 Aug 2019.

Pesonen, M., and J. Könönen. 1973. Lapin Kulta 100 vuotta 1873-1973 [Lapland's Gold 100 years 1873-1973]. Oulu: Lapin Kulta.

Pint General. 2019. Tornion panimo - Tunturipurot solisevat taas [Tornio Brewery - fell streams are burbling again; online]. https ://pintgeneral.com/2019/08/02/tornion-panimo-tunturipurot-solis evat-taas/. Accessed 20 Dec 2019.

Pizzi, G., and D. Scarpi. 2019. The year of establishment effect on brand heritage and attitude. Journal of Consumer Marketing 36(6): 827-834.

Pulizzi, J. 2012. The rise of storytelling as the new marketing. Publishing Research Quarterly 28(2): 116-123.

Riviezzo, A., A. Garofano, J. Granata, and S. Kakavand. 2017. Using terroir to exploit local identity and cultural heritage in marketing strategies: An exploratory study among Italian and French wine producers. Place Branding and Public Diplomacy 13(2): 136-149.

Rose, G.M., A. Merchant, U.R. Orth, and F. Horstmann. 2016. Emphasizing brand heritage: Does it work? And how? Journal of Business Research 69(2): 936-943.

Sallinen, M. 2017. Tornion panimon emoyhtiö alkaa viljellä humalaa [Tornio Brewery's holding company will begin to cultivate hops; 
online]. https://www.lapinkansa.fi/lappi/tornion-panimon-emoyh tio-alkaa-viljella-humalaa-200450009/. Accessed 29 Aug 2019.

Sangen. 2016. Sangen: osakeanti [Sangen: share issue]. Oulu: Sangen.

Schnell, S.M. 2013. Deliberate identities: Becoming local in America in a global age. Journal of Cultural Geography 30(1): 55-89.

Schnell, S.M., and J.F. Reese. 2003. Microbreweries as tools of local identity. Journal of Cultural Geography 21(1): 45-69.

Schnell, S.M., and J.F. Reese. 2014. Microbreweries, place, and identity in the United States. In The Geography of Beer: Regions, Environment, and Societies, ed. M. Patterson and N. Hoalst-Pullen, 167-187. Dordrecht: Springer Netherlands.

Shortridge, J.R. 1996. Keeping tabs on Kansas: Reflections on regionally based field study. Journal of Cultural Geography 16(1): 5-16.

Sjölander-Lindqvist, A., W. Skoglund, and D. Laven. 2019. Craft beer-Building social terroir through connecting people, place and business. Journal of Place Management and Development 13(2): 149-162.

Smith, T. 2011. Brand salience not brand science: A brand narrative approach to sustaining brand longevity. The Marketing Review 11(1): 25-40.

Smith Maguire, J., and S. Charters. 2020. Aesthetic logics, terroir and the lamination of grower champagne. Consumption Markets \& Culture. https://doi.org/10.1080/10253866.2020.1730823.

Spear, S., and S. Roper. 2013. Using corporate stories to build the corporate brand: An impression management perspective. Journal of Product and Brand Management 22(7): 491-501.

Spielmann, N., A. Discua Cruz, B.B. Tyler, and K. Beukel. 2019. Place as a nexus for corporate heritage identity: An international study of family-owned wineries. Journal of Business Research. https:// doi.org/10.1016/j.jbusres.2019.05.024.

Stern, B.B. 1994. Authenticity and the textual persona: Postmodern paradoxes in advertising narrative. International Journal of Research in Marketing 11(4): 387-400.

Stern, B.B., C.J. Thompson, and E.J. Arnold. 1998. Narrative analysis of a marketing relationship: The consumer perspective. Psychology and Marketing 15(3): 195-214.

Taylor, S., Jr., and R.B. DiPietro. 2020. Assessing consumer perceptions of neolocalism: Making a case for microbreweries as placebased brands. Cornell Hospitality Quarterly 61(2): 183-198.

Teerijoki, I. 2010. Tornion historia 3: 1918-2000 [The History of Tornio 3: 1918-2000]. Tornio: Tornion kaupunki.

Thurnell-Read, T. 2019. A thirst for the authentic: Craft drinks producers and the narration of authenticity. The British Journal of Sociology 70(4): 1448-1468.

Tornion Panimo. 2016a. Brewery [online]. http://www.tornionpanimo. fi/brewery/. Accessed 29 Aug 2019.

Tornion Panimo. 2016b. Our story [online]. http://www.tornionpanimo. fi/our-story/. Accessed 29 Jan 2018.

Tornion Panimo. 2017. Tornion panimo. Juomaopas. [Tornio Brewery. Drink Guide; online]. https://issuu.com/finland/docs/juomaopas. Accessed 4 Jan 2018.
Turunen, M. 2002. Jos täytätte mun lasini: Suomalaisen panimoja virvoitusjuomateollisuuden vuosisata $=$ the century of the Finnish brewing and soft drinks industry. Helsinki: Panimo- ja virvoitusjuomateollisuusliitto.

Urde, M., S.A. Greyser, and J.M. Balmer. 2007. Corporate brands with a heritage. Journal of Brand Management 15(1): 4-19.

Uusitalo, H. 2018. Panimoyhtiö toivoo saavansa kunnon humalasadon Pyhäsalmen kaivoksesta - "Projekti näyttää oikein lupaavalta" [Brewing company hopes to have a plentiful hop harvest from the Pyhäsalmi mine - "The project looks very promising"; online]. https://www.kaleva.fi/uutiset/talous/panimoyhtio-toivoo-saavansakunnon-humalasadon-pyhasalmen-kaivoksesta-projekti-nayttaaoikein-lupaavalta/795175/. Accessed 20 Dec 2019.

Wiedmann, K.-P., N. Hennigs, S. Schmidt, and T. Wuestefeld. 2011. Drivers and outcomes of brand heritage: Consumers' perception of heritage brands in the automotive industry. Journal of Marketing Theory and Practice 19(2): 205-220.

Wilson, R.T. 2018. Transforming history into heritage: Applying corporate heritage to the marketing of places. Journal of Brand Management 25(4): 351-369.

Withers, E.T. 2017. The impact and implications of craft beer research: An interdisciplinary literature review. In Craft Beverages and Tourism, Volume 1: The Rise of Breweries and Distilleries in the United States, ed. C. Kline, S. Slocum, and C. Cavaliere, 11-24. Cham: Palgrave Macmillan.

Woodside, A.G., S. Sood, and K.E. Miller. 2008. When consumers and brands talk: Storytelling theory and research in psychology and marketing. Psychology \& Marketing 25(2): 97-145.

Zelinsky, W. 2011. Not yet a placeless land: tracking an evolving American geography. Amherst: University of Massachusetts Press.

Publisher's Note Springer Nature remains neutral with regard to jurisdictional claims in published maps and institutional affiliations.

Janne P. Ikäheimo works as a lecturer in archaeology at the University of Oulu. While his dissertation (2003) focused on ceramic cooking pots produced in Roman Africa, his current research interests include neo-relics in contemporary society, the early medieval period in Northern Finland and the use of native copper in eastern Fennoscandia and northwest Russia during the Neolithic. As a self-taught beer aficionado, he is also interested in the material culture, marketing and sociology of craft beer. 